OPEN ACCESS

Citation: Alexander Johannes Edmonds (2021) Just a Series of Misunderstandings? Assyria and Bīt-Zamāni, Hadi-/lhtadi-libbušu, and Aramaic in the early Neo-Assyrian State. Asia Anteriore Antica. Journal of Ancient Near Eastern Cultures 3: 73-91. doi: 10.36253/asiana-1188

Copyright: (c) 2021 Alexander Johannes Edmonds. This is an open access, peer-reviewed article published by Firenze University Press (http://www. fupress.com/asiana) and distributed under the terms of the Creative Commons Attribution License, which permits unrestricted use, distribution, and reproduction in any medium, provided the original author and source are credited.

Data Availability Statement: All relevant data are within the paper and its Supporting Information files.

Competing Interests: The Author(s) declare(s) no conflict of interest.

\section{Just a Series of Misunderstandings? Assyria and Bīt-Zamāni, Hadi-/Iḩtadi-libbušu, and Aramaic in the early Neo-Assyrian State}

\author{
Alexander Johannes Edmonds \\ Institute for the History of Ancient Civilizations, Northeast Normal University, \\ Changchun \\ alexander-johannes.edmonds@uni-tuebingen.de
}

\begin{abstract}
The region of the Upper Tigris serves as a key case study in understanding the early expansion of the Neo-Assyrian Empire. Nevertheless, various aspects of its incorporation within the Neo-Assyrian pale remain obscure, particularly the date and nature of the establishment of the province of Amēdu or Na'iri, previously the Aramean polity of Bīt-Zamāni. After a summary of prior arguments and an investigation of the polity's Middle Assyrian past, two overlapping and complimentary histories are written, one of the political interactions between Assyria and Bìt-Zamāni, and another of Assyria’s provincialisation of the Upper Tigris. The former finds that Bìt-Zamāni was remarkably resilient in the face of Assyrian aggression, while the latter argues that an early Assyrian presence at Damdammusa was replaced in $879 \mathrm{BC}$ by the provinces of Sinābu/Na'iri and Tušhhan. These two histories are then supplemented by a prosopographical investigation of the Assyrian eponym of $849 \mathrm{BC}$, the first attested governor of Na'iri, one Hadi-libbušu or Ihtadi-libbušu. It is demonstrated that the two contemporaneous variants of his name within the Assyrian textual corpus may be explained as an ambiguity in translating the Aramaic personal name * $h d h l b b h$ into Akkadian for use as an eponym date. It is hence likely that Hadi-/Ihtadi-libbušu was an indigenous potentate made governor, and thus that the polity of Bìt-Zamāni serves as a previously unrecognised example of the Postgatian 'transitional case' within the Early Neo-Assyrian Empire analogously to Bīt-Bahiāni/Gūzāna. Indeed, it is argued that a similar phenomenon of translating the transitional ruler/governor's name into Akkadian for limmu dating may here be attested for Gūzāna’s two initial governors. In light of these findings, their broader implications for the use of Aramaic in correspondence or record-keeping within $9^{\text {th }}$ century Assyria are considered, and it is suggested that Hadi-/Ihtadi-libbušu's correspondence was conducted in Aramaic, whence scribes must have had recourse in spelling this potentate's name. This would mark the earliest use of Aramaic within the Neo-Assyrian bureaucracy presently known. It is then finally concluded that the threat of Urarțu in the last years of Aššur-nāșir-apli II's reign may well have compelled him to enter in a manner of compact with BìtZamāni, and that the indigenous rulers were thereafter made Assyrian governors, only to be unseated in favour of Ninurta-kibsi-uṣur, šăqiu rabiu to Salmānu-ašarēd III just prior to Amēdu's rebellion in the succession war of 826-820 BC, after
\end{abstract}


which it was conclusively incorporated. Some insufficiencies of present theories of Neo-Assyrian imperialism in explaining this complex historical scenario are finally highlighted.

Keywords. Upper Tigris, Neo-Assyrian Empire, Aramaic, bilingualism, expansion, Amēdu/Diyarbakır, Bīt-Zamāni, Gūzāna/ Tell Halaf.

\section{INTRODUCTION}

The region of the Upper Tigris presents a vital scenario for investigating Neo-Assyria's expansion, particularly considering the wealth of archaeological and philological information which might be brought to bear. ${ }^{1}$ Separated from the Fertile Crescent by the Ṭūr 'Abdīn, the ancient Kāšiāri, its enclosed basin witnessed Assyrian intervention, conquest, settlement, and provincialisation both in the Middle and Neo-Assyrian eras, rendering it a fascinating counterpoint to contemporaneous historical phenomena on the Upper Huābūr. Like the latter region, an archaeological image of excellent resolution has emerged over the past decades, the most exemplary thereof being the Assyrian provincial capital of Tušhana, ${ }^{2}$ where a plethora of information on the late Neo-Assyrian settlement including monumental architecture, cuneiform documents, and floral and faunal remains has been evinced. In turn, extensive surveying and further investigations at companion sites have provided a fuller picture of the Assyrian settlement pattern. ${ }^{3}$

Rich and informative as this history of the Assyrian Upper Tigris basin has become, archaeological and philological knowledge of the important Aramean polity of Bìt-Zamāni and its capital at $\mathrm{Amēdu}^{4}$ has remained scant, and often Assyria's interactions with it have been portrayed as little more than a prelude to the construction of the Assyrian province of Tušhan. ${ }^{5}$ Despite the difficulty and apparent contradictions of many of the textual sources available, it is nonetheless the present author's conviction that the heavily disputed issue of the date and nature of Bīt-Zamāni's annexation can be satisfactorily solved, and a new history of this historical scenario written.

This is accomplished through the undertaking of two parallel but interconnected histories of Assyria and BitZamāni in the early Iron Age. The first of these focuses upon Assyria's interactions with this Aramean polity and Machtpolitik within the region. The second of these examines Assyria's early provincialisation of the Upper Tigris. These two histories overlapping in time and space demonstrate that the actual history of Bìt-Zamāni/Amēdu's integration into the Upper Tigris region was far more complicated and nuanced than has previously been understood. From these, the personage of the first governor of Amēdu attested today as both Hadi-libbušu and Ihtadi-libbušu within Assyrian dating formulae is investigated, and the puzzling alternate versions of his name within the Assyrian textual record explained. The evidence collected is then compared to the 'transitional case' of Bìt-Bahiāni/Gūzāna. Before a concluding reconstruction is presented of the annexation of Bìt-Zamāni/Amēdu, the repercussions of the

1 This article is an expanded version of a subchapter of the present author's doctoral dissertation, Warum eroberst du obne Ende?' Studies in the Birth of the Neo-Assyrian Empire (Edmonds 2018), the publication of which is forthcoming. A discrete publication was undertaken on the strength of the interesting and unnoticed figure of Hadi-/Ihtadi-libbušu, the repercussions of his name for the integration of client states during the $9^{\text {th }}$ century BC, and its contribution to the history of Aramaic within Assyria. The present author extends his gratitude to Andreas Fuchs, John MacGinnis, Herbert Niehr, and an anonymous reviewer for their comments during this paper's initial draft. The present author's views remain his own, his spelling of ancient and modern toponyms generally follows the normalisation principles of the TAVO's register, and of personal names generally the PNA.

${ }^{2}$ Almost indisputably modern Ziyaret Tepe, Turkey. For a very recent summary of excavations undertaken here, see Matney et al. 2020.

${ }^{3}$ Cf. recent syntheses in Szuchman 2009; Köroğlu 2016; Matney 2010; Matney et al. 2020; Wicke 2013.

${ }^{4}$ Modern Diyarbakır, Turkey. The present author follows TAVO's vocalisation of Amēdu, despite some misgivings due to the byname Andi (cf. fn. 13).

5 A particularly egregious example thereof is Parker's treatment of the Upper Tigris, in which a lengthy recapitulation of Assyria's interactions with Bīt-Zamāni (2001: 165-173) abruptly concludes with Salmānu-ašarēd III in favour of discussing the establishment of the province of Tušhan. Amēdu is later mentioned only in passing (e.g. 228, fns. 1007 and 1008). 
onomastic findings on Hadi-/Ihtadi-libbušu are briefly discussed in relation to the history of the use of Aramaic in the Neo-Assyrian Empire. Firstly, however, the problem of the annexation of Bït-Zamāni/Amēdu must be considered.

\section{THE PROBLEM OF BĪT-ZAMĀNI'S ANNEXATION}

The writing of the history of the annexation of territories to the māt Ayšur generally follows a series of historical inferences. On the one hand, the eponym (or limmu) lists and chronicles and administrative texts hailing from the established empire are exhaustively scoured for the names of governors of provinces, presenting a diachronic array of first attestations of various provinces, and, on the other, annalistic accounts of campaigning by Assyrian kings are studied to identify expansion. These two sets of information are then harmonised. Archaeological evidence is generally employed to support these claims where necessary. Such intricate work demands constant refinement as new information becomes available. ${ }^{6}$

Two provinces are attested within the Upper Tigris during the later stages of the Assyrian Empire, namely the aforementioned province of Tušḩan, inaugurated 879 BC by Aššur-nāșir-apli II, and a province known as Na'iri, Sinābu, Amēdu, or Bīt-Zamāni. ${ }^{7}$ The date of the second province's inauguration generally hinges upon the reconstruction of a period of seventeen years between the failure of Aššur-nāṣir-apli II to capture Amēdu in 866 BC and the appearance of the limmu year, or eponym, of one Hadi-libbušu or Ihtadi-libbušu, governor of the land of Na'iri, in $849 \mathrm{BC}$. The only extant occurrence punctuating this is a brief and uneventful account of Salmānuašarēd III's march through the land of Bīt-Zamāni in $856 \mathrm{BC}^{8}{ }^{8}$ Following Hadi-/Ihtadi-libbušu, the eponym of another governor is known, one Ninurta-kibsi-ușur, from $838 \mathrm{BC}$, although he still governed Rașappa at the time, and must only have later been posted to Na'iri. Finally, Amēdu rebelled during the succession war which rocked Assyria between 826 and $820 \mathrm{BC}^{9}$ but was brought once more to heel soon thereafter. ${ }^{10}$

The point at which Bīt-Zamāni became an Assyrian province has long been debated. Views generally fall within one of two camps, namely those proposing an annexation between 866 and $849 \mathrm{BC},{ }^{11}$ and those championing a later incorporation during the last quarter of the $9^{\text {th }}$ century. ${ }^{12}$ Both views rest upon complex inferences.

The 866-849 camp adopts an argument rooted in the eponym lists and the Stelenreiben of Aššur; while very convincingly armed with Hadi-/Ihtadi-libbušu's limmu in 849 BC, the major stumbling block of the argument is that the geographical extent of his province is unknown, and must be inferred from Aššur Stelae nos. 39 and 47, which belong to the later governors Marduk-šimanni (eponym for 799 BC) and Ninurta-kibsi-uṣur (eponym for $838 \mathrm{BC}$ ) respectively. Amēdu does not appear on these stelae, but rather 'Andi', which must hence be taken as a byname for the city. ${ }^{13}$

\footnotetext{
${ }^{6}$ The most comprehensive recent study is Radner 2006 b.

${ }^{7}$ Radner 2006b: 49-50. Na'iri was the Assyrians' traditional moniker for the broader region, Sinābu was the name of the most prominent 'Assyrian' city within its extent, previously its Middle Assyrian provincial capital.

8 'Moving on from the city Kār-Salmānu-ašarēd, I crossed over Mount [Ha]sumu and went down to the land of Bīt-Zamāni. Moving on from the city of Bīt-Zamāni, I crossed over Mounts Namdānu and Merhisu.' (A.0.102.1 ii 40-41 = Grayson 1996: 19).

9 'When Aššur-da"in-apla, at the time of Salmānu-ašarēd (III), his father, acted treacherously by inciting insurrection, uprising, and criminal acts, caused the land to rebel and prepared for battle; (at that time) the people of Assyria, above and below, he won over to his side, and made them take binding oaths. He caused the cities to revolt and made ready to wage battle and war. The cities Nineveh, Adia, Šibaniba, Imgur-Enlil, Iššabri, Bīt-Šašširia, Šìmu, Šibhinišs, Tamnuna, Kipšūna, Kurbail, Tīdu, Nabulu, Kahat, Aššur, Urakka, Raqmat, Huzirīna, Dūr-balāṭi, Dariga, Zaban, Lubdu, Arrapha, and Arbail, together with the cities Amēdu, Tīl-Abnē, and Hindānu, — altogether twenty-seven towns with their fortresses which had rebelled against Salmānu-ašarēd (III), king of the four quarters, my father, sided with Aššur-da" in-apla. By the command of the great gods, my lords, I subdued (them).' (A.0.103.1 i 39-53 = Grayson 1996: 183).

${ }^{10}$ For a list of known governors of Amēdu, see Radner and Schachner (2001: 770-772).

${ }^{11}$ Kessler 1980: 100-102; Radner 2006b: 49.

12 Forrer 1920: 30; Lipiński 2000: 160-161; Younger Jr. 2016: 306.

${ }^{13}$ A correction of an-di to $t i$ - $d i$, i.e. the Assyrian settlement of Tìdu, seems unlikely considering that Andi appears both in Stelae nos. $37 \& 49$. A reduction of Amēdu to Andi suffers from the fact that the toponym's middle vowel has otherwise weathered the ravages
} 
Those suggesting a later annexation generally focus their argument upon the nondescript accounts of the campaigns of 856 and $830 \mathrm{BC}$ which could be taken to imply an enduring vassaldom on Bìt-Zamāni's part, and the description of the succession war of 826-820 BC, which may intimate that Amēdu was still a client state at the time, rather than a province. ${ }^{14}$ Nonetheless, the proponent of Amēdu's clientship up to the last quarter of the $9^{\text {th }}$ century must contend with the unequivocal attestation of two governors of Na' iri prior to Amèdu's rebellion.

Having introduced the basic argumentation, the main historical investigations of this paper may begin in earnest; prior to this, however, a brief study of the preceding Middle Assyrian period must be undertaken.

\section{BĪT-ZAMĀNI IN THE MIDDLE ASSYRIAN PERIOD}

The first attestation of Bīt-Zamāni hails from the $13^{\text {th }}$ century, referring to a hassihlu of the halzu of BìtZamāni. ${ }^{15}$ This startlingly early reference would locate it firmly within the era in which Assyrian kings conquered much of the Upper Tigris during their Mitannian campaigns. ${ }^{16}$ While the actual extent of their conquests remains difficult to judge, a reference to Šināmu ${ }^{17}$ in an administrative document detailing the dispatch of hurādu-troops for work there during the reign of Salmānu-ašarēd ${ }^{18}$ heavily implies the establishment of an Assyrian presence in the region focused upon this city. ${ }^{19}$ This would have been accompanied by the creation of dunnu-settlements as typified by the site of Giricano and other hallmarks of Middle Assyrian provincialisation. ${ }^{20}$

of time, appearing as 'Amida' during Late Antiquity and as 'Amed' among Kurdophones today. Comparison with 'Amādīya in modern Kurdish Iraq (possessing the same Semitic etymology' $m d$ as the supertigridine toponym under discussion) is perhaps instructive. While vocalised with a long second vowel in Arabic, it has been reduced to 'Amedya by those of its inhabitants who speak NorthEastern Neo-Aramaic (cf. Greenblatt 2011: passim). It is entirely possible that two parallel forms reflecting alternate interpretations existed in parallel, thus Akkadian 'Amēdu' (= *'amīd) implying a QaTīL construction, and an Aramaic 'Āmed following Lipiński reconstruction of a QāTiL (Lipiński 2000: 153). While Amēdu’s medieval Arabic spelling 'Āmid is fronted by an alif madda, the loss of the initial 'ayn only muddies things further.

${ }^{14}$ As already noted by Forrer (1920: 30) the three final cities declaring for Aššur-da"in-apla, Amēdu, Til-Abnē, and Hindānu are separated from the other twenty-four by the particle adi, implying that the latter threesome were still-unincorporated clients, which is, indeed, borne out by the case of Tìl-Abnē, and Hindānu.

15 lúha-síh-li ša hal-zi É za-ma-ni (Billa 6, 1.8 = Finkelstein 1953: 124-125). Younger is wary but offers no alternate reading (Younger Jr. 2016: 293-294).

${ }^{16}$ Hence well before the appearance of the other Aramean polities of the bitu-type.

17 To be equated with Neo-Assyrian Sinābu. While localised at Pornak since Kessler (1980: 111-120), this is a consequence of Kessler having already assigned the important site of Üçtepe (find site of the Kurh Stelae) to Tīdu. This, in turn, was motivated by an equivalence between the Mitannian capital of Taidu and Neo-Assyrian Tīdu as mentioned on Aššur-nāṣir-apli II's Kurh Stele. Advancements in present knowledge now place Mitannian Taidu squarely in the Upper Hābūr (cf. Röllig 1983), most likely at Tall al-Hamīdīya, and, indeed, all Neo-Assyrian references to a Tīdu or Tēdu save that on Aššur-nāṣir-apli II’s Kurh Stele are also best situated there; cf. especially its aforementioned appearance among superchaburine cities siding against Šamši-Adad V in A.0.103.1 i 39-53 (= Grayson 1996: 183) and a täkultu text's reference to a Samanuha of Tēdu, otherwise best known from Šadikanni's pantheon (cf. Pongratz-Leisten 2011: 121). The logical conclusion is that the Assyrian historical geographer's favourite bugbear, toponymie en miroir, has struck again, and that Aššur-nāṣir-apli II’s Upper Tigridian Tīdu was less than consequential for Assyrian history, pace Radner and Schachner 2001: 756-757; Schachner 2018: 108-109. To Sinābu must go the spoils of Üçtepe with its monumental late Neo-Assyrian structures (cf. Köroğlu 2016: 315); given the provincial history further outlined herein, this is entirely cogent.

${ }^{18}$ KAV 119 (cf. Jakob 2003: 206-207).

${ }^{19}$ Note also the reference to the pāhatu of Šināmu in the Broken Obelisk of Aššr-bēl-kala (A.0.89.7 14 = Grayson 1991: 102), which would imply its provincialisation. Both Šināmu and Tušhan are mentioned in the Giricano documents and a considerable Middle Assyrian occupation is attested for Tušhan, but there is not sufficient textual evidence to infer that the latter was its own province. Brown's notion that Šināmu's lack of attestation in the ginäu lists implies that they were never officially incorporated into the Middle Assyrian state is interesting, but lacks further evidence (Brown 2013: 114).

${ }^{20}$ See the recent survey of the Middle Assyrian Upper Tigris in Düring (2020: 83-86). 
In considering Bìt-Zamāni itself, its designation as a halzu is key; while this term's precise use and semantics remain disputed, ${ }^{21}$ a defensive connotation seems likely. ${ }^{22}$ In turn, the title hassihlu may imply a culturally Hurrian origin for the region's administration. ${ }^{23}$ Nonetheless, its marcher lord's solidly Assyrian name of Aššur-kāšid son of Bēl-qarrād demonstrates that this region was under Assyrian control. ${ }^{24} \mathrm{~A}$ similar practice may also be evidenced for a region southwest of Šināmu, Eluhatat, conquered by Salmānu-ašarēd I and colonised by Assyrians, later termed Halziluha in Neo-Assyrian sources. ${ }^{25}$ Quite evidently, the Assyrian settlements founded on the wide plains of the Upper Tigris were protected by halzu-districts such as the two evidenced, presumably appended to the province.

Aramean troubles of the $12^{\text {th }}$ and $11^{\text {th }}$ centuries seem to have heavily undermined the Middle Assyrian state's authority in the region and may have led to the abandonment of the lowland settlements. ${ }^{26}$ Despite the chaos intimated by mention in Broken Obelisk of Ašsur-bēl-kala of a battle with Arameans at Dunnu-ša-Libur-zāninAššur ${ }^{27}$ in the pāhatu of Šināmu, the White Obelisk of Aššur-nāșir-apli I ${ }^{28}$ describes the king pursing an enemy north of the Kāšiāri. ${ }^{29}$ It is probably apt to consider the Upper Tigris to have been in a state of political flux. ${ }^{30}$ As will be further discussed, this instability would seem to have given both the relict Assyrians of the region and the polity of Bīt-Zamāni a necessity for self-reliance and sense of independence which would hamper Assyrian efforts in the region during the Iron Age. What must also be stressed is that Bīt-Zamāni’s past as a fringe military holding of the Middle Assyrian state may well explain the unusual and invasive relationship which Assyria had with its vassal in the $9^{\text {th }}$ century, and its later history.

\section{BİT-ZAMĀNI IN THE ASSYRIAN (RE-)CONQUEST OF THE UPPER TIGRIS}

While no campaigns to the Upper Tigris region can yet be attested for the reign of Aššr-dān II, his early reimposition of vassaldom upon the kingdom of Katmuhu on the north of the modern Cizre plain was a necessary precondition for such..$^{31}$ His successor Adad-nārārī II's explosive campaigning featured an early concentration upon the Upper Tigris, to which he ventured four times. ${ }^{32}$ This likely began in $908 \mathrm{BC}$, and was certainly concluded in

${ }^{21}$ Cf. Postgate 1995: 1-2. That pāhatu 'province' and halzu were not conceived of as exactly interchangeable is demonstrated by MARV 4, 119 (cf. Llop 2012: 93).

22 Cf. Jakob 2003: 18.

23 This raises the fraught question of Bīt-Zamāni’s etymology, and hence ethnic composition; Zadok posits a Hurrian etymology to explain the earliness of this attestation (1991: 113), while Lipiński elects for a conventional Semitic interpretation (2000: 135-136). The latter is probably to be preferred, but for want of more information this must remain open.

${ }^{24}$ Note the same's appearance, along with his son, at Šibaniba, although it remains unclear as to whether this was coterminous with his posting there or not (cf. Machinist 1982: 22-23).

${ }^{25}$ A.0.101.1 i 101-103 (= Grayson 1991: 200). Cf. Liverani 1992: 99; Postgate 1995: 1.

26 The end of the Giricano archive around 1068 BC being a case in point (Radner 2004: 115).

${ }^{27}$ Note Fales' recent emendation of this toponym (2012: 103).

${ }^{28}$ The present author considers the White Obelisk an inscription of Aššur-nāșir-apli I; this is founded not only in the incompatibility of its account with the early reign Aššur-nāṣir-apli II, but also in its affinities with the other texts presently attributed to Aššur-nāṣirapli I (cf. discussion in Frahm 2009: 117-123).

${ }^{29}$ A.0.101.18 '18-'33 (= Grayson 1991: 256).

${ }^{30}$ Brown 2013, cf. Roaf and Schachner 2005.

31 A.0.98.1. 33-41; A.0.98.2 17'-22' (= Grayson 1991: 133-134; 137). See Radner 2006a on passage through the Tūr 'Abdīn. Generally overlooked are the eastern routes into the Upper Tigris region, such as those offered via the plains of Şırnak and Siirt. While arduous for a large army such as Xenophon's Ten Thousand, they would not have posed exceptional difficulties to messengers or small caravans. The course of the Tigris itself can also be followed; Layard did so, heading southwards by way of Çelikköy and descending into the plain of Cizre at Findik (Layard 1853: 50-51). See also Comfort and Marciak 2018: 34-41.

32 A.0.99.2 30 (= Grayson 1991: 148). 
$903 \mathrm{BC}^{33}$ The first two and probably the fourth of his campaigns are fragmentarily extant, ${ }^{34}$ describing chevauchées into the Upper Tigris. At some point during these campaigns, he annexed three formerly Assyrian towns which had fallen to Šubria. ${ }^{35}$

It is only come Tukultī-Ninurta II that Bìt-Zamāni swims into focus; the close of a campaign in $887 \mathrm{BC}$ presents a unique occurrence within the annals, a miniature campaign of sorts conducted by the son of Ammi-ba'li against one Bialasi in Udu of the land of Nirdun on Assyria's behalf, forwarding the spoils to Assyria. ${ }^{36}$ That a campaign by a local polity ostensibly performed on the Assyrian king's behest would make it into the annals is astounding enough, but is easily surpassed by the events of the following year.

In $886 \mathrm{BC}$, a figure with a fragmentary name and title ${ }^{37}$ wrote to Tukultī-Ninurta II stating that Bīt-Zamāni had further aspirations in the region, seeking, indeed, to march through the Kāšiāri. Tukultī-Ninurta II pre-empted this and ravaged the countryside around the city of Patiškun belonging to Bīt-Zamāni, depriving the region of grain and putting Ammi-ba'lī's sons to the sword. This harrying must have driven Bīt-Zamāni to negotiate; Ammiba'lī submitted, and Assyria took spoils from his palace. Most striking, however, is that Tukultī-Ninurta II had its ruler Ammi-ba'lī swear that Bīt-Zamāni would no longer sell horses to any power but Assyria. ${ }^{38}$ This singular agreement was accompanied by two other unusual developments, namely that Assyrian officials were stationed within Bìt-Zamāni, and the displaced population of Bīt-Zamāni was peacefully internally resettled by TukultīNinurta II. ${ }^{39}$ The significance of this reference to horses cannot be stressed enough. ${ }^{40}$ Assyria's anxieties that rival polities may gain a superiority in horses likely fuelled her endless campaigns to the Zagros even during the first half of the $8^{\text {th }}$ century BC. ${ }^{41}$

While Ammi-ba'lī delivered tribute in $882,{ }^{42}$ he was assassinated in a putsch in 879 BC by the nobles of Bīt-Zamāni and one Bur-Rammān, which prompted Aššur-nāșir-apli II to return to the region, have BurRammān flayed at Sinābu, confiscate the polity's considerable wealth, impose a much higher tribute, and deport some 1500 Ahlamean soldiers in Ammi-ba'lī’s pay to Assyria. ${ }^{43}$ Ilānu, Ammi-ba'lìs brother, ${ }^{44}$ was installed as the new client ruler.

Following the leanly attested mid-period of the king's reign, during which he likely fought inconclusive skirmishes with the transeuphratine polity of Bìt-Adini and then undertook his much-lauded 'March to the Sea', Aššrur-nāṣir-apli II returned to the region for the last time, burning his way along the Euphrates and annexing the

\footnotetext{
33 This analysis, and that of Tukulti-Ninurta II's campaigns which follows is the result of the present author's ascription of five unattributed royal inscriptions published by Eckart Frahm (2009) to Adad-nārārī II and Tukultī-Ninurta II, as outlined in the appendix of the present author's unpublished doctorate (Edmonds 2018). A discrete publication of these findings is in preparation.

${ }^{34}$ Na'iri Campaigns $1 \& 2$ = VAT 10107 (= Frahm 2009: 97-98, no. 47); Na'iri Campaign 4 = VAT 11320, 1s.1'-6' (= Frahm 2009: $104-105$, no. 53).

35 A.0.99.2 35 (= Grayson 1991: 149). This evidences direct territorial expansion in the region for the first time, and raises the question of these conquests' administration, to be discussed in the following section.

${ }^{36}$ A.0.100.5 4-8 (= Grayson 1991: 171).

${ }^{37}$ See discussion in the following section.

38 A.0.100.5 24-25 (= Grayson 1991: 171-172).

${ }^{39}$ A. 0.100 .5 20-24 (= Grayson 1991: 171-172). This exceptional situation strangely blends vassalage and provincialisation, with Assyria seeking to influence Bīt-Zamāni internally far more than was usual with a client kingdom, see the following section.

${ }^{40}$ Sworn before the local divinity of Adad, this may be the earliest attestation for the later commonplace adê oath. It should be recalled that Tukulti-Ninurta II's reign also witnesses the first evidence of the use of cavalry by the Assyrian army (A.0.100.5 $37=$ Grayson 1991: 173).

41 The efforts made by the Assyrians to maintain a superiority in horses are striking cf. Āl-sūsānī, i.e. 'horse trainer-town' (Bagg 2017: 26). Other evidence of the value placed upon horses includes ritual activity to protect them within the Assyrian army (Maul 2013).

42 A.0.101.1 ii 12 (= Grayson 1991: 202).

43 See Edmonds 2019a for discussion of Ahlameans in the Iron Age.

44 The ambiguous wording of the annals has led many to consider Ilānu Bur-Rammān's brother despite the counter intuitiveness of this arrangement, cf. Sano (2015).
} 
region of Mallānu by the modern Karacadağ. ${ }^{45}$ Damdammusa had defected to Bīt-Zamāni and it was forced to surrender Ilānu's men, whom Aššur-nāșir-apli II proceeded to impale before the city of Amēdu. Despite this shock and awe, ${ }^{46}$ Aššur-nāșir-apli II's final assault on Amēdu proved all but fruitless, save for the orchards that he hacked down. ${ }^{47}$ On the route home, the king pillaged the most likely unsuspecting settlement of Udu nestled in the Țür 'Abdin, ${ }^{48}$ presumably to collect some token loot both to placate his army and to gild an otherwise lukewarm triumphal return to Assyria. The absence of any further annalistic accounts of campaigns for the remainder of this monarch's reign perhaps intimates to the scrappy nature of his final years, likely preoccupied with the outbreak of war with Urarțu. ${ }^{49}$

Ten years later and some 175 miles or so to the southwest, Salmānu-ašarēd III departed from Tīl-Barsip, ${ }^{50}$ marching up the Euphrates to strike at the very heart of Urarțu by way of the Upper Tigris, a deed immortalised in a royal epic still read in the last years of the Assyrian Empire. ${ }^{51}$ His passage through Bì-Zamāni was uneventful, as was that of his turtānu Dayyān-Aššur in 830 BC, some 19 years after the first attestation of a governor there.

What this survey of the interactions of Assyria with Bît-Zamāni and their occasional hostilities demonstrates is the striking dynamism of this supertigridine Aramean polity. Not only did it undertake its own campaigning, but it even threatened to march over the Kāšiāri. In turn, it successfully enticed Damdammusa to its side, and made other territorial gains. ${ }^{52}$ Its wealth is apparent from its ability to field chariotry and its stores of metals. In turn, its nobility seemed repeatedly keen to rebel from Assyria, perhaps more from confidence than desperation. This is demonstrated by the absence of the city of Amēdu from Assyrian sources prior to 866 BC; its strategic position was easily defensible ${ }^{53}$ and all Assyria could do was to ravage the countryside around. It seems unlikely that Aššrur-nāșir-apli II succeeded in conquering this difficult city during the remainder of his reign without leaving an account, and the absence of more than passing mention of the polity in Salmānu-ašarēd III's annals is also telling. Most likely, a diplomatic solution of some sort was undertaken by Assyria between 866 and 856 BC.

\section{BĪT-ZAMĀNI IN THE PROVINCIALISATION OF THE UPPER TIGRIS}

That some manner of Assyrian 'pre-provincial'54 structure was already in place in the Upper Tigris prior to the inauguration of Tušhan in $879 \mathrm{BC}$ is evidenced from various intimations of such within the textual record. Firstly, Adad-nārārī II's early annexation of three formerly Assyrian towns which had fallen to Šubria ${ }^{55}$ must be

\footnotetext{
45 A.0.101.1 iii 101 (= Grayson 1991: 220).

46 The city's resistance is a remarkable example of the potential ineffectiveness of Aššur-nāṣir-apli II's 'calculated frightfulness' (cf. Olmstead 1918).

${ }^{47}$ A.0.101.1 iii 109 (=Grayson 1991: 220). See Cole 1997 for discussion of this common Assyrian tactic.

${ }^{48}$ Already the target of Bìt-Zamāni’s campaigning in $887 \mathrm{BC}$.

49 As has been convincingly argued by de Filippi, the variance between Aššur-nāșir-apli II's geographical summaries stating 'to Nērbi' and 'to Urarțu' clearly demonstrates a significant later campaign to Urarțu by this king (1977). Cf. Grayson's commentary to A.0.101.1 iii 122 (Grayson 1991: 221).

${ }^{50}$ Modern Tall Ahmar, Syria.

51 Today preserved in a damaged copy from Sultantepe, SAA 317 (= Livingstone 1989: 44-47). Interesting therein is a frustratingly fragmentary reference to his father's campaigning (1. 16).

52 Note also that the settlement of Barzania, subjugated by Tukulti-Ninurta II (VAT 9752 \& 9782 = Frahm 2009: 92-97, nos. 45-46, 1. 17’) appears to have fallen into Bīt-Zamāni’s hands come $866 \mathrm{BC}$, should it be identical to the town of Barzaništun (A.0.101.1 iii $104=$ Grayson 1991: 220).

53 Ammianus Marcellinus notes a natural spring within its walls within his description of the siege of Amida: 'In ipso autem Amidae meditullio sub arce fons dives exundat, potabilis quidem, sed vaporatis aestibus non numquam faetens.' (Res Gestae XVIII, 9, 2, cf. Rolfe 1950: 464); indeed, a stone tunnel with a spring was also recently identified underneath Amida's mound. The present author is grateful to the team from Dicle Üniversitesi for an impromptu tour of the site.

54 The present author employs Liverani's terminology (1992: 115) for want of a better expression.

55 A.0.99.2 35 (= Grayson 1991: 149).
} 
considered. ${ }^{56}$ Secondly, Tukultī-Ninurta II was warned of Bīt-Zamāni's imminent march across the Țūr 'Abdīn in $886 \mathrm{BC}$ by a figure who may have been a governor. ${ }^{57}$ The candidates for such an individual within the $9^{\text {th }}$ century Upper Hābūr are thin, ${ }^{58}$ and a 'man on the spot' in the Upper Tigris seems more likely. ${ }^{59}$ In turn, following his confrontation of Bīt-Zamāni during the same campaign and swearing of oaths, Tukultī-Ninurta II installed officials to supervise the polity; ${ }^{60}$ it seems unlikely that such an implementation would have been effective were there not an existing Assyrian administration in the region to support them.

Proceeding from these inferences, concrete candidates for a location for this might be considered. Within Ašsurnāșir-apli II's Kurh Monolith, the tribute gathering of 879 BC is described as having been centred upon four cities, Tušhan, Sinābu, Tìdu, and Damdammusa; ${ }^{61}$ the first of these is qualified as having just been rebuilt after a period of decline, ${ }^{62}$ while Sinābu and Tīdu are stated to have been reclaimed from the 'Arameans' the same year. ${ }^{63}$ It must hence be concluded that Damdammusa was the only significant Assyrian-held settlement in the Upper Tigris prior to this episode, and hence the focal point of Assyrian control; indeed, Damdammusa is termed an àl sarrütìya 'city of my kingship' in Aššur-nāṣir-apli II's annals, implying that it contained an Assyrian royal residence. ${ }^{64}$

In turn, the Kurh Monolith not only relates the establishment of Tušhan, but also the provincialisation of regions of Na'iri. ${ }^{65}$ These would logically have been assigned to Sinābu considering its later synonymy with the province of Na' iri. ${ }^{66}$ It hence seems apparent that both Sinābu/Na'iri and Tušhan were formally established in 879 $\mathrm{BC}$, and that this constellation replaced a previous situation in which Damdammusa was the key Assyrian possession in the region, irrespective of whether or not it is to be considered an early province; the explanation for this is to be found in the rebellion of Hūuāaya.

In 882 BC, Aššur-nāșir-apli II received a report that one Hūāāya, lord of the relict Assyrians of Hualziluha had been courting the city of Damdammusa. The inhabitants of Halziluha, the descendants of Assyrians settled by Salmānu-ašarēd I, ${ }^{67}$ would have been largely left to fend for themselves and co-operate with neighbouring groups such as Hurrians, Arameans, or habhu-folk, creating a manner of independent 'frontier spirit'. ${ }^{68}$ Something of the relative egalitarianism usually exhibited by offshoot societies may well be reflected in the name of the leader of the

\footnotetext{
56 The nearest province to which they could have been appended at this early date would have been Katmuhu on the other side of the Kāšiāri. It is conceivable that 'pre-provincial' Assyrian territory was notionally a direct possession of the king, which could explain the frequent use of ana ramāniya așbat in the annals and the assignment of rough border zones to members of the royal court.

57 A.0.100.5 24-25 (= Grayson 1991: 171-172). Grayson reads GÌR?.ARAD?, i.e. šakkanakku. Should this reading be correct, then it would be highly unusual; this highly antiquated title was restricted to the Assyrian king's titulary during the Neo-Assyrian period.

${ }^{58}$ No eponyms from the period fit the traces ]-la- $a$ ? Should it be presumed that one of the governors of the Upper Hābūr had been tasked with the surveillance of the Upper Tigris and reported this on to the king, then it would presumably be that of Katmuhu or Raqmat, Nașibina having only been annexed the previous year after the violent rebellion described in VAT 14402 (= Frahm 2009 : 108-111, no. 56; cf. appendix in Edmonds 2018). While Raqmat was not particularly close to the Țür 'Abdīn, the Assyrian outpost of Huzirina would likely have fallen within its territory. Regardless, the strange title of sakkanakku would hardly fit such an ascription.

59 It is tempting to identify this mysterious šakkanakku ]-la-a? with none other than Hūlāya, the leader of the relict Assyrians of Halziluha.

${ }^{60}$ A.0.100.5 20-24 (= Grayson 1991: 171-172).

${ }^{61}$ A.0.101.1997 (= Grayson: 261).

${ }^{62}$ A.0.101.1 ii 2-7 (= Grayson 1991: 201).

${ }^{63}$ A.0.101.19 92-94 (= Grayson 1991: 261).

${ }^{64}$ A.0.101.1 i 103 (= Grayson 1991: 200). Note that when this city defects to Bīt-Zamāni it is termed Ilānu's 'fortified city' in contrast to his own 'royal city' of Amēdu (cf. discussion of this term in Ikeda 1979).

${ }^{65}$ A.0.101.19 99-100 (= Grayson 1991: 262).

${ }^{66}$ Note also in this context Aššur-nāṣir-apli II's annexation of Mallānu, attested as part of Na'iri in Aššur Stelae nos. 39 and 47, in $866 \mathrm{BC}$ on the way to Amēdu (A.0.101.1 iii 101 = Grayson 1991: 220).

${ }^{67}$ A.0.101.1 i 101-103 (= Grayson 1991: 200). While it is entirely possible that they were settled by Salmānu-ašarēd II, his forbear's mention of conquering Eluhat and the parallelism with Bït-Zamāni in the $13^{\text {th }}$ century renders him the preferable candidate.

68 Pace Dewar (2020: 116-117) whose Conradian parallels and ideological dichotomy between 'Assyrian' and 'non-Assyrian' hardly capture the region's complexity during this period.
} 
wayward Assyrians, Hūlāya, 'The one of the road' or 'Roadling', possibly a name for a foundling. ${ }^{69}$ They most likely resented the return of external Assyrian power to the region. The close of this rebellion saw it quashed and Hūlaya flayed at Damdammusa. The two major flayings of this period recorded, Hūlāya at Damdammusa in 882 and BurRammān at Sinābu in 879 BC, both occurred at key locations; that the king meted justice over Bīt-Zamāni from Sinābu is telling considering both the Middle Assyrian past and that these territories would be amalgamated but decades in the future into a single province.

Aššur-nāșir-apli II's creation of a new provincial structure in the aftermath of this insurrection sought to end the power monopoly of this less than reliable Assyrian city. This, in turn, neatly explains Damdammusa's defection to Bìt-Zamāni around $866 \mathrm{BC}$; having lost its previously privileged status in the region, the city sided with its wealthy neighbour. In the wake of this provincial reorganisation and Aššr-nāṣir-apli II's failure before Amēdu in 866, it may be presumed that they did not undergo any further territorial changes until Sinābu absorbed Bìt-Zamāni.

856 BC witnessed Salmānu-ašarēd III's march through Bīt-Zamāni as detailed, and the first known governor of $\mathrm{Na}$ 'iri is attested thereafter as the eponym for $849 \mathrm{BC}$, one Huadi-libbušu or Ihtadi-libbušu. For many scholars, this serves as the terminus ante quem for Bīt-Zamāni's annexation. The next attested governor of the region is Ninurta-kibsī-uṣur, eponym for 838 BC albeit still governor of Rașappa then..$^{70}$ His governance of Amēdu is suggested rather by Ašsur Stele no. 47, wherein he is styled šăqiu rabiu and ascribed the holdings of Andi, Sinābu, Suhna, Mallānu and Alzu; ${ }^{71}$ that these constituted the province of Amēdu is demonstrated by the Aššur stele of the next known incumbent, one Marduk-šimanni, eponym for 799 , which is near-identical in its toponymy. ${ }^{72}$

Ninurta-kibsi-ușur's stint in charge of Na'iri presents some interesting features. The title of šăqiu rabiu is first attested in the reign of Aššr-nāșir-apli II and appears to have existed parallel to the better-known office of rab $s ̌ a ̄ q e \hat{e}$, or cupbearer. ${ }^{73}$ Considering that Mulissu-mukannišat-Nīnua, queen of Aššur-nāṣir-apli II and Salmānuašarēd III, was the daughter of the earlier šăqiu rabiu Aššur-nīrka-da"in, it might be assumed that this was an influential position. In turn, the province of Rașappa had grown to become a vast and distended province by Salmānu-ašarēd III's time, encompassing the lower course of the Ȟābūr, the Middle Euphrates down to Sūhnu, and the Sinğār by this period, the province effectively dividing the extreme west of Assyria's realm from the heartland. ${ }^{74}$ It may well be that Ninurta-kibsi-ușur's appointment to this post and the assignment of the province of Na'iri's territory was an attempt by the king to alter the balance of power between his various magnates and to sever Ninurta-kibsi-ușur's connection with his powerbase. ${ }^{75}$

Another potential thesis for Ninurta-kibsī-ușur's posting is that Salmānu-ašarēd III may have been experimenting with the creation of marcher provinces along Assyria's wilder borders, as is far better known from the late

\footnotetext{
${ }^{69}$ Consider the analogous foundling names Suqäa or Šulâ/Šulâya 'One of the street, Streetling' common in Babylonia, the latter also borne by a hapless messenger to the Zagros in a likely portion of the Na'id-ŠîHU Epic (Edmonds 2019b: 329-330). Hūlāya would be the logical equivalent of such a name within a more rural setting. The assignment of distinct names to foundlings is frequently attested within ancient cultures; besides the mythical example of Oedipus, 'swollen-foot', in reference to his laming on his abandonment, the infamous case of the assignment of 'copronyms' to infants found on dunghills in Hellenistic Egypt serves as a particularly striking example (cf. Pomeroy 1986).

${ }^{70}$ Finkel and Reade wish to amend the entry for $838 \mathrm{BC}$ which displays $r$ ]a-șap-pa to Na'iri on grounds of Ninurta-kibsi-uṣur appearing as the governor of Na'iri on Aššur Stele no. 47 (= Andrae 1913: 53-54, cf. Millard 1994: 111) and suspect that dittography is responsible for this writing (Finkel and Reade 1998: 248), but this is unnecessary.

${ }_{71}$ Andrae 1913: 53-54.

72 Andrae 1913: 49.

${ }^{73}$ Mattila 2000: 47-48.

${ }^{74}$ See Radner 2006b: 52-53 and recently Parpola 2017. After reaching its zenith under Pālil-ereš, who may even have sought to incorporate Sühu into Assyria under his own initiative, the province was subdivided. While Laqû had become a discrete province by 736 BC at the latest, Halzi-adbāri's mention in Tukulti-apil-Ešarra III’s inscription at Mila Mergi from 739 BC would imply an even earlier division, should this province be localised in the Sinğār, formerly Rașappa’s north-easternmost reaches, a proposition which is, however, still uncertain, as Cizre is probably the better source of basalt (adbāru) within the vicinity of ancient Ulluba.

${ }^{75}$ Indeed, the latter half of Salmānu-ašarēd III's reign is already characterised by the emergence of powerful officials jockeying for positions, cf. esp. Fuchs 2008; Grayson 1994.
} 
Neo-Assyrian period. ${ }^{76}$ In 830 BC, Salmānu-ašarēd III's turtānu Dayyān-Aššur passed through Bīt-Zamāni once more on campaign to Urarțu, ultimately trouncing Sarduri I. $^{77}$ Regardless of when precisely Ninurta-kibsī-ușur's Amidine incumbency had begun, it was likely brought to a close with the outbreak of the succession war in 826 which engulfed Assyria in Salmānu-ašarēd III's terminal years.

An interesting archaeological correlate in this context is a perceived reduction in activity at Ziyaret Tepe following the reign of Salmānu-ašarēd III, ${ }^{78}$ perhaps due to the chaos of the rebellion, or perhaps from the region bracing itself for a coming Urartian onslaught. To the Assyrians' credit, it would seem that this defensive strategy largely succeeded; save a foray by Minua, the Urarțians ultimately circumvented the region and extended their influence down to the Syro-Aramaic polities of the west by way of the western bank of the Euphrates until Tukultī-apil-Ešarra III dramatically broke their hold west of the Euphrates in the opening years of his reign. With $745 \mathrm{BC}$ and the advent of empire proper, the present history of the region may conclude. A final interesting point is the survival of the name Bìt-Zamāni into the later stages of the empire, not only in the eponym lists and imperial correspondence, ${ }^{79}$ but also in an Aramaic missal. ${ }^{80}$

The later profusion of names for this province, i.e. Na'iri, Amēdu, Sinābu, and Bīt-Zamāni is striking. It may well be that this phenomenon genuinely belies a battle of precedence between Sinābu/Na' iri, the senior settlement, erstwhile capital, and 'Assyrian' face of the province, and Amēdu/Bït-Zamāni, the natural city from which to govern, ${ }^{81}$ but also an Aramean addition to the original province. Having presented these two histories, the figure of Huadi-/Ihtadi-libbušu may now be investigated.

\section{HADI-LIBBUŠU OR IHUTADI-LIBBUŠU, THE FIRST GOVERNOR OF NA'IRI}

Little ink has been spilt on Hadi-libbušu or Ihtadi-libbušu, ${ }^{82}$ and, quite surprisingly, the peculiar variation in his name has not yet been explicitly discussed within academic literature. It is first expedient to consider the various attestations of this figure and their details.

As might be noted, these attestations are all associated with his eponymate. Outside of date formulae, nothing is known presently to have been written of him by Assyrian hand. Nonetheless, something of his origins and career might be inferred; his name serves as a reasonable point of departure.

Firstly, it should be noted that the individual Hadi-libbušu (Akk. 'His heart is joyful') also occurs as Ihtadilibbušu (Akk. 'His heart rejoiced') within the Neo-Assyrian textual record; these variants present differing forms of the same verb in Akkadian, had $\hat{u}$, 'to rejoice'. While to the present author's best knowledge otherwise unattested, both are plausible and grammatically correct Akkadian personal names. In turn, despite these two names' clear semantic propinquity, they are both phonologically and graphically distinct enough that arbitrary confusion between them seems unlikely.

While it is common to misremember an individual's name for one perhaps better known, ${ }^{83}$ it must be recalled that Hadi-/Ihtadi-libbušu's name appears solely in the context of his eponymate. His name would have been used

\footnotetext{
${ }^{76}$ Support for this notion is lent by the die of the masennu Aya-hālu (or Yahālu), mentioning his governorship of the difficult westernmost flank of the Zagros (cf. Millard 1994: 8-front.).

77 A.0.102.14 141-146; A.0.102.16 228'-267’ (= Grayson 1996: 69, 81).

${ }^{78}$ Cf. Köroğlu 2016.

${ }^{79}$ For example, Nashir-bēl, governor of Amēdu in Šarru-ukīn's reign, himself refers to his province as such in correspondence.

${ }^{80}$ Mirrored in an attestation of bny zmn in an Aramaic document from Tall Šiūh Fawqānī (cf. Fales et al. 2005: 609, fn. 101).

${ }^{81}$ On a clear day, one can still see across the entire Upper Tigris basin from Diyarbakur's citadel today.

82 See Ambos 2000. Remarkably, Lipiński’s otherwise exhaustive discussion of Bīt-Zamāni omits any mention of Hadi-/Ihtadi-libbušu (Lipiński 2000: 160-161). This name is to be distinguished from the otherwise attested and near homophonous apotropaicon Hāêelīpušū 'Let the malevolent do (as they wish)!', perhaps to be read Ḩādê-lipūšū 'May they scorn the ill-wishers!'.

${ }^{83}$ Correspondence postal, telephonic, and electronic addressed to one 'Mister Edwards' is a strange and irksome constant in the present author's life.
} 
Table 1. Attestations for Hadi-/Iḩtadi-libbušu.

\begin{tabular}{|c|c|c|c|c|}
\hline Graphy & Reference & Provenance & Date & Comment \\
\hline$\overline{\mathrm{m}} h a-d i-i[$ & A 1 ii 14 & Nineveh & last entry 659 & eponym list \\
\hline${ }^{\mathrm{m}} h a-d i l i-b u-[$ & A 2 ii 4 ' & Nineveh & last entry c. $670 ?$ & eponym list \\
\hline${ }^{\mathrm{m}} h a-d i l i-b u-s ̌ u$ & A 6 i 6 & Nineveh & last extant entry 697 & eponym list \\
\hline$d] i l i-b u-s ̌ s$ & A 7 vi 25 & Aššur & last extant entry 659 & eponym list \\
\hline${ }^{\mathrm{m}} h a-d[i$ & A 8 ii 7 & $\begin{array}{c}\text { Sultantepe (ancient } \\
\text { Huzurīna) }\end{array}$ & last entry 750 & eponym list \\
\hline 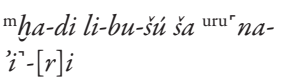 & B 5 i 1 & Nineveh & $\begin{array}{l}\text { fragment, last extant } \\
\text { entry } 847\end{array}$ & eponym chronicle \\
\hline$\left[{ }^{\mathrm{m}}\right] h a-d i l i-b[u$ & Billa 77 r. 1 & Tell Billa (ancient Šibaniba) & dated 845 & $\begin{array}{l}\text { eponym date mentioned in administrative } \\
\text { text describing military drafts }\end{array}$ \\
\hline $\begin{array}{l}\mathrm{m}_{i h-t a-d i} l i-b u-{ }^{2} u \text { GAR } \\
\mathrm{kur}_{n a-i-r i}\end{array}$ & RIMA 3 A.0.102.18:21' & Aššur & dated 849 & $\begin{array}{c}\text { eponym date on clay clone containing } \\
\text { annalistic account }\end{array}$ \\
\hline $\left.\mathrm{m}_{i h-t a-d[u} \ldots\right]^{\mathrm{uru}_{s i-}}{ }$ & RIMA 3 A.0.102.18:21' & Aššur & dated 849 & $\begin{array}{c}\text { eponym date on clay clone containing } \\
\text { annalistic account }\end{array}$ \\
\hline $\begin{array}{l}]-t a-d u l i-b u-s^{s} u[\ldots] \\
\text { kur } n a-i-r i\end{array}$ & As 3975:5' & Aššur & dated 849 & eponym date on clay clone \\
\hline $\begin{array}{l}i] h-t a-d u l[i \quad .1]^{1} \text { GAR } \\
\text { KUR kur } n a-{ }^{r} i^{\urcorner}-[\text {ri }]\end{array}$ & As 9094:4 & Aššur & dated 849 & eponym date on clay clone \\
\hline
\end{tabular}

universally within the Assyrian administration not only during the year of his incumbency, but also for years thereafter, ${ }^{84}$ this rendering the confusion between these two forms even stranger; sheer legal and administrative imperative would dictate a modicum of uniformity.

The present author should like to propose the following solution in light of these remarks, namely that this name had been translated from Aramaic, and that an ambiguity in the writing of the original name provoked these variant appellations; indeed, should the names Huadi-libbušu and Ihtadi-libbušu be translated into Old Aramaic as a thought experiment, ${ }^{85}$ then the results are as follows:

\begin{tabular}{ccc}
\hline Akkadian & Old Aramaic & Aramaic orthography \\
\hline HUadi-libbušu $^{86}$ & *hāde-libbeh ${ }^{87}$ & ${ }^{*} h d b l b b h$ \\
Ihtadi-libbušu $^{88}$ & *ḥadā-libbeh & ${ }^{* 9}$ hdhlbbh \\
\hline
\end{tabular}

As is evident, while both Aramaic forms of the name are easily distinguished aurally, they are nonetheless graphically identical. Without foreknowledge or context, a reader cannot deduce the pronunciation or semantics of this name due to its ambiguous writing, then as now. While Assyrian royal annals and private and administrative documents alike can sport strange manglings of Aramaic personal names, this individual's name had been chosen to date a year, and hence its precise rendering would have been necessary. Accordingly, the present author suggests

${ }^{84}$ That Ihtadi-libbušu was merely misremembered as Hadi-libbušu by the compilers of the eponym lists and chronicles perhaps centuries later is effectively discounted by the Billa tablet, composed only four years after the eponymate, when the year name would have remained in the collective memory.

85 The Old Aramaic vocalisation in Folmer (2011) is here employed; for $h d y$ as a translation for Akk. had $\hat{u}$, cf. Hoftijzer and Jongeling 1995, vol. 1: 349, sub. hidy .

86 3. s. stat. G hadû.

${ }^{87}$ masc. s. act. part. $h d y$.

88 3. s. perf. G hadû.

89 3. s. perf. $h d y$. 
that the scribes of the Assyrian administration resolved to translate this individual's name into good Akkadian; ${ }^{90}$ unfortunately, however, there were two competing schools of thought, and both translations became common within the administration before a single rendering could be standardised. ${ }^{91}$

As is immediately apparent, underlying this interpretation of an otherwise perplexing state-wide administrative contradiction is the crucial premise that the name was known only known to the scribes of the Assyrian bureaucracy in Aramaic writing and not orally. Nevertheless, Hadi-/Ihtadi-libbušu's position as governor of an Aramaic-speaking province on the far edge of Assyria's extent renders this not implausible. In turn, it is no great step to assume that Hadi-/Ihtadi-libbušu hailed from this very region, and, indeed, that he was, in fact, also the local ruler following Ilānu. This inference is rendered all the more plausible when the similar situation within another Neo-Assyrian province of the $9^{\text {th }}$ century BC is considered, Bīt-Bahiāni/Gūzāna, a so-called 'transitional case'.

\section{BĪT-ZAMĀNI AS A TRANSITIONAL CASE}

J. Nicholas Postgate's seminal article 'The Land of Assur and the Yoke of Assur'92 first introduced what he termed 'transitional cases', client states exhibiting some but not all of the hallmarks of incorporation into the NeoAssyrian Empire during the $9^{\text {th }}$ century. ${ }^{3}$ While various examples of this may be found within the Neo-Assyrian textual and archaeological record, ${ }^{94}$ the present author should like to focus upon the prominent example of BitBaḩiāni/Gūzāna.

The Aramean polity of Bït-Bahiāni coalesced within the radius of the newly founded Iron Age settlement of Güzāna ${ }^{95}$ in the $11^{\text {th }}$ to $10^{\text {th }}$ centuries BC in a region with a long history of imperial endeavour, most saliently embodied in the nearby settlement of Sikānu, formerly the Mitannian capital of Waššukkan(n)i, which had also played host to a Middle Assyrian administration before finally adopting a primarily cultic function during the early Iron Age. ${ }^{96}$ Gūzāna swiftly became affluent should the somewhat outlandish monumental structure of Kapara be anything to go by.

In stark contrast to its more easterly neighbours, Nașibīna and Gidāra/Raqmat, Bīt-Bahiāni did not war with Assyria in the $9^{\text {th }}$ century BC, but rather remained circumspect, rendering tribute when approached by Adad-nārārī II, but allowing him access solely to Sikānu. ${ }^{97}$ Aššur-nāșir-apli II's annals also present an image of docile clientdom. ${ }^{98}$

\footnotetext{
90 The translation of Aramaic personal names into Akkadian is a well attested phenomenon, the most famous example being the later Assyrian queen Naqīa/Zakūtu.

91 The implications that this bears for the workings of the Assyrian administration in the $9^{\text {th }}$ century are discussed at this article's close. Various solutions present themselves for the peculiar writing ha-di-i beyond mere scribal mistake, none of which is particularly enticing. Firstly, considering that a break ensues, it is plausible that this is, in fact, a hypochoristicon, i.e. Hadî, although a cursory perusal of the eponym lists did not yield any other examples of commensurate informality in year-naming. Another solution is that a scribe took ha-di as a nominal form within an omitted anticipatory genitive construction, i.e (Ša-)hadî-libbušu 'The joy (of) his heart', and thus spelt it plene as ha-di-i. Finally, at a very considerable stretch, ha-di-i could be taken as an Assyrianised 2. f. s. imp. D, thus Haddî-libbušu 'Make him happy!', the obvious downside of this being the male addressee. Of these, the second option is perhaps the least miserable.

92 Postgate 1992.

93 'This was not the same as the later practice of attaching an Assyrian agent to a local court, best attested in the Phoenician ports. Rather, it entailed replacing the local ruler by, or converting him into, a 'governor' answerable to the king, but probably not the incorporation of his territory or local administration into the Assyrian system proper, as they do not appear to have been provincial governors of the regular variety' (Postgate 1992: 257).

${ }^{94}$ Brevity demands the selection of a single case study. To Postgate's examples of Gūzāna and Sūhu may, in the present author's mind, be added Hindānu and the holdout Assyrian local dynasty at Šadikanni likely only unseated come the succession war. Additional textual documentation and further detailed historical investigation would likely yield more such examples.

95 Modern Tall Halaf, Syria.

${ }^{96}$ Cf. the very recent overview from Elsen-Novák and Novák (2020).

${ }_{97}$ A.0.99.2 100-104 (= Grayson 1991: 153).

${ }_{98}$ A.0.101.1 iii 57-58 (= Grayson 1991: 216).
} 
No mention is made of the polity within annalistic accounts of Salmānu-ašarēd III's campaigning, and it is assumed to have been incorporated into the empire during this period. Indeed, its first governor, Šamaš-nūrī, is attested as eponym for 866 BC, the next, Adad-rēmanni, for 841 BC. Finally, an Assyrian campaign to the city is known from 808 $\mathrm{BC}$, the region having evidently gone its own way during the chaos of the latter quarter of the $9^{\text {th }}$ century.

A tidy end to Bìt-Bahiāni's sovereignty in $866 \mathrm{BC}$ at the very latest would be a done deal were it not for a celebrated bilingual inscription of Adad-it'i/Adda-yis'ī, son of Šamaš-nūrīin, in Aramaic and Akkadian discovered at Tall Fahhhāriya. ${ }^{99}$ As is now well known, the inscription styles both of them as governor, šaknu, in the Akkadian, and as king, malk, within the Aramaic. It is this ambiguity between languages and the lack of any concomitant political events which renders Bït-Bahiāni a transitional case within the expansion of the early Neo-Assyrian Empire; the local rulers had been dubbed governors within the Neo-Assyrian 'co-prosperity sphere', but evidently continued to depict themselves as Aramean kings to their own populace.

The question of translation and ambiguity runs even deeper in this case, and becomes at once highly pertinent to the present study inasmuch as the common Assyrian name Adad-rēmanni 'Adad have mercy on me!' of 841 BC's limmu is not dissimilar to the Aramaic name of the Fahhārīya inscription's commissioner, Adda-yis'í 'Adda is my help'. This has prompted the suggestion that Adad-it'i/Adda-yis'îs's name had been translated into Akkadian ${ }^{100}$ for the sake of eponym dating. Beyond a chronological congruency, ${ }^{101}$ this is supported in the present author's mind by a crucial point, namely that while Adda-yis î's name is rendered Adad-it'i in Akkadian, this is in the cuneiform of his own, local inscription; it cannot be proven that the Assyrian central bureaucracy at all referred to him as such. ${ }^{102}$ In turn, the same inscription reveals Šamaš-nūrī to have been Sās-nūrī (ssnwry) all along. ${ }^{103}$ The uprising ending in 808 BC, after which Gūzāna would have found itself under the governance of the obviously Assyrian Mannu-kīAššur, thus spelt the end of a local dynasty. Even then, Gūzāna would rebel again between 759 and 758 BC, and BītBahiāni is even referenced in the Book of Isaiah, this demonstrating an enduring local identity. ${ }^{104}$

The parallels to Bīt-Zamāni's fate are at once apparent, and it might reasonably be suggested that Amēdu was an Upper Tigridian example of such a 'transitional case'. Both cases evidence affluent and powerful Aramean polities with traditions rooted in the Late Bronze Age. In both cases, no forceful takeover can be evidenced, and, in turn, the governors are most likely local rulers in Assyrian guise whose names were translated into Akkadian for the eponym list. ${ }^{105}$ This last point must be examined against the backdrop of the history of Aramaic within early Neo-Assyrian administration.

\footnotetext{
99 See Dušek and Mynářová 2016 for a recent edition of this inscription and discussion.

100 'This quite common type of Akkadian proper names may have been used as an Assyrian adaptation of Hadd-yit'i's Aramaic name. Incidentally, no other eponym of that period bears a name with the theophorous element Hadd/Adad.' (Lipiński 2000: 129). Dornauer concurs with this assessment (2010:57).

${ }^{101}$ Adad-it'i must otherwise be shoehorned in between his father in 866 and Adad-remanni in 841; it must be hypothesised thereby that the junking of the local dynasty did not spell any unrest worthy of mention in extant Assyrian sources, but that a rebellion occurred come $808 \mathrm{BC}$ for reasons unrelated. By means of comparison, the endurance of the local ruling family until their final replacement by Mannu-kī-Aššur raises little in the way of further difficulties, and is hence to be preferred for want of evidence to the contrary.

${ }^{102}$ Note Younger's erroneous objection on grounds that ' $[\mathrm{t}]$ he Akkadian scribes were entirely capable of translating the Aramaic name into Akkadian: Adad-it'i' (Younger Jr. 2016: 265). 'Adad-it'i' is not a translation of 'Adda-yis'í', but rather a partial 'Akkadisation', as 'it' $i$ ' is merely a phonetic rendering of 'yis'i' without semantic import.

${ }^{103}$ Due to the closeness and occasional mutual comprehensibility of these languages, the distinctions between a phonetic rendering of an Aramaic name by means of cuneiform, the 'Akkadianisation' of an Aramaic name, and its outright 'translation' are often ambiguous; whether Sās-nūrī himself would have considered 'Šamaš-nūrì' an Akkadisation or a translation of his name is unclear.

${ }^{104}$ Demsky 2008.

105 While there are eponyms with Aramaic names already attested in the $9^{\text {th }}$ century, such as Il-milkī and Aya-hālu the masennu, and perhaps Yarî, there is no evidence that these had previously been local rulers. Indeed, should they have belonged to the Assyrian court, as Aya-halu must have, then an entirely different milieu from the governors of 'transitional cases' could be assumed for these individuals; current scarcity of evidence precludes judgement.
} 


\section{ON THE USE OF ARAMAIC IN THE EARLY NEO-ASSYRIAN STATE}

A final issue raised by the thesis of this paper is that of the use of Aramaic and the Aramaic script within the $9^{\text {th }}$ century Neo-Assyrian sphere. As has been contended, the confusion between Hadi-libbušu and Ihtadi-libbušu could only have occurred if the bureaucracy of the Neo-Assyrian heartland was in possession of the first governor of Amēdu's name in Aramaic script but were unsure as to its vocalisation in Aramaic, and hence created two competing Akkadian translations of his name. This implies that Hadi-/Ihtadi-libbušu's correspondence as governor would have been written in Aramaic, and whatever of it reached the Assyrian heartland's bureaucracy was not concertedly, centrally, or systematically translated into Akkadian, but rather consulted on the fly by scribes, and presumably translated as required, if at all; moreover, were there to have been a 'card index' of Assyrian potentates then the first governor of $\mathrm{Na}$ 'iri had evidently been either omitted or double filed. This finding has considerable bearing both on the history of the development of the Aramaic script, and on its use within Neo-Assyrian administration.

The precise dissemination of the Aramaic alphabet eastwards from Phoenicia to the Upper Hābūr and finally the Assyrian world is difficult to trace. ${ }^{106}$ Something of a milestone for present purposes is an inscribed altar from Tall Halaf which dates to the early $9^{\text {th }}$ century, ${ }^{107}$ a few decades at most before the creation of the Fahhārīya Inscription. ${ }^{108}$ By means of contrast, Kapara's inscriptions of the previous century had been in crude Akkadian. In the case of Bīt-Zamāni, Tukultī-Ninurta II's annals exceptionally appear to quote verbatim a letter from Ammiba'li's son to the Assyrian king; ${ }^{109}$ unfortunately, its brevity and broken state permit scarce judgement on whether this had been written in Akkadian with Aramaicisms or in Aramaic and subsequently translated for the annals. ${ }^{110}$

Turning to Assyria, intimations as to the advent and degree of adoption of Aramaic within the Neo-Assyrian state apparatus are scant. ${ }^{11}$ Perhaps the earliest traces of Aramaic within an institutional context are the bricklayer's marks found at Fort Shalmaneser at Kalhu, ${ }^{112}$ albeit these were for the benefit of workmen, not scribes. ${ }^{113}$ Come the era of Adad-nārārī III, the Nimrud Wine Lists attest for the first time to Aramean scribes within a palatial setting. ${ }^{114}$ In turn, the first depiction of the thereafter common trope upon reliefs of two scribes counting spoil, one with tablet and stylus, the other with pen and scroll, hails from Tukultī-apil-Ešarra III's Central Palace at Kalhu. ${ }^{15}$ The tight proximity of this pair in all attested examples implies some manner of institutionalised tandem documentation. With the famous letter from Šarru-ukin demanding letters be written in Akkadian rather than Aramaic, ${ }^{116}$ the floodgates were well and truly open. ${ }^{117}$ Rare Aramaic texts such as the Aššr Ostracon imply that colleagues within the administration might tend to write each other missals on other media in between com-

\footnotetext{
106 See discussion in Gzella 2015: 57-63.

${ }^{107}$ KAI 309, cf. Dankwarth and Müller 1988.

${ }^{108}$ Cf. linguistic discussion in Gzella 2015: 63-67.

109 A.0.100.5 5-6 (= Grayson 1991: 171).

110 nota bene, however, Lipiński’s interesting reconstruction of a phrase within this passage as ištu Udu ana Šūaru ana silihi irtedīma 'he went from Udu to Šararu within this javelin's throw' which he takes as an Aramaicism analogous to a Hebrew phrase found twice in the Book of Job (Lipiński 2000: 139-140). There is no Akkadian word silihu, and this would have to have come from Aramaic slah, itself only weakly attested.

${ }^{111}$ Elsen-Novák and Novák (2020: 146-147) present an interesting, albeit highly tenuous equivalence of the script of Taymä’ as mentioned by Yariri of Carchemish with the Temanite Arameans of the Upper Ḣābūr and hence the Aramaic script. Were such an admittedly conjectural thesis proven to hold, then it would imply an earlier dispersal of the Aramaic script eastwards into the Assyrian sphere than otherwise thought.

112 Millard 2008: 268.

113 Considering that the bricks formed a cuneiform inscription when assembled correctly together, however, it may well be that a scribe literate in cuneiform had been the one who had patiently annotated these bricks with Aramaic letters prior to their transport to the building site so as to prevent any mix-ups.

${ }^{114}$ CTN 1, no. 9, rev. 20 (=Wilson 1972: 138).

115 See discussion in Reade 2012: 706.

116 SAA 17, 3 (= Dietrich 2003: 5-6).

117 Cf. Beaulieu 2006.
} 
posing tablets, ${ }^{118}$ while themes known later from Aramaic 'romances' may already have permeated Assyrian literary compositions. ${ }^{119}$

Considering the present overview, the correspondence from Hadi-/Ihtadi-libbušu, although not extant, would nonetheless serve as the earliest present attestation for the use or at least reception of Aramaic within the NeoAssyrian state's administration.

\section{CONCLUSION}

The elements are now all present to present a new portrait of Bìt-Zamāni's incorporation within the māt Ǎssur. In the first historical section, it was demonstrated that Bīt-Zamāni was a more powerful force in the Upper Tigris than is usually depicted. Not only was it affluent, but it also pursued an active foreign policy, campaigning within the Upper Tigris basin and even planning to march over the Kāšiāri against Assyria herself. In the following section on the provincial history of the region, it has been established that the political reality in the Upper Tigris was more complicated than the pristine establishment of the provinces of Tušhan in $879 \mathrm{BC}$ and Na'iri in $856 \mathrm{BC}$ respectively often advanced. Rather, an Assyrian administration at Damdammusa existing perhaps already in the reign of Adad-nārārī II was replaced in $879 \mathrm{BC}$ with two provinces, Na'iri/Sinābu and Tušhhan, in response to difficulties with the local Assyrian population. While Na'iri/Sinābu did not encompass Bīt-Zamāni/ Amēdu, the meting of justice to Bur-Rammān on Sinābu's walls already presaged a provincial relationship akin to that during the Middle Assyrian period. In turn, although Aššur-nāșir-apli II’s invasion of Bīt-Zamāni due to Damdammusa's insurrection proved futile, the Aramean polity was once more under heel come 856, and had a governor by $849 \mathrm{BC}$.

These two overlapping histories converge in this very figure, Hadi-/Ihtadi-libbušu, who, it has been argued, possessed an Aramaic name which had been translated in conflicting manners into Akkadian by Assyria's central bureaucracy. This, in turn, suggests that he was an indigenous ruler promoted to governor, an example of the Postgatian 'transitional case'. The clear parallels to Bīt-Bahiāni/Gūzāna, another Aramean polity on the edge of the Assyrian pale, would seem to support this. Indeed, it has been argued that the names of its first two governors, whose incumbencies coincide with that of Hadi-/Ihtadi-libbušu, also had their names translated into Akkadian for the benefit of the eponym systems. This translation implies that their correspondence would have been in Aramaic, and that Assyrian scribes translated this ad hoc and as required within their bureaucracy.

From these findings, the date and nature of Bīt-Zamāni/Amēdu's annexation might finally be resolved. With hostilities with Urarțu on the horizon, Aššur-nāṣir-apli II made a startling volte face and reconciled with Ilānu at some point in the years following his failed siege of $866 \mathrm{BC}$, making him governor of the province of Na'iri/ Sinābu/Amēdu/Bīt-Zamāni and thus amalgamating the Assyrian and Aramean holdings into an uneasy single territory. ${ }^{120}$ While a compromise, it ensured the region's safety, much as the halzu of Bīt-Zamāni had in the Middle Assyrian era, and access to the equines vital to Assyria's military. This situation continued with Hadi-/Ihtadilibbušu, who was even 'honoured' with an eponymy, and the indigenous dynasty was only unseated with Salmānuašarēd III's installation of the powerful Ninurta-kibsī-ușur at some point after $838 \mathrm{BC}$, most likely in $830 \mathrm{BC}$ when Dayyān-Aššur passed through the region. This situation likely provoked Amēdu's subsequent revolt during the succession war of 826-820 BC, ${ }^{121}$ after which it was likely placed under Assyrian governorship again, Mardukšimanni appearing as its governor and eponym in 799 BC. As a 'transitional case' between perhaps already 865 and

\footnotetext{
118 Cf. Fales 2010.

${ }^{119}$ Edmonds 2019b: 344.

120 This could potentially explain the broken line of the Salmānu-ašarēd III Epic wherein it is stated 'Aššur-nāșir-apli harnessed and mobilized the land of Na'iri [ ....]' (SAA 3 17, 16 = Livingstone 1989: 44).

${ }^{121}$ Note that this presents a potential harmonisation of the rebellion of Amēdu during the succession war of 826-820 BC: Its stint as a 'transitional case' had only just concluded and the Šamši-Adad V's scribes still considered it such in their list of rebellious cities. Or, it could be presumed that Ninurta-kibsī-uṣur never actually arrived at his new posting prior to the rebellion's outbreak.
} 
$830 \mathrm{BC}$, the date of its actual annexation depends entirely on one's own definition. This finding naturally bears repercussions for the further investigation of Assyria's expansions, especially during the $9^{\text {th }}$ century.

As has been demonstrated, contradictions and ambiguities in the governance of the early Neo-Assyrian realm are to be understood as precisely such. A coherent doctrine of Assyrian expansion as known from the reign of Tukultî-apil-Ešarra III onwards with its irreversible three-step program of initial contact to client state to Assyrian province struggles to explain the complexities of the $9^{\text {th }}$ century, and has yielded controversy over Bīt-Zamāni's annexation. Diachronic and thematic studies of the early Neo-Assyrian period grounded in an understanding of Middle Assyrian precedent ${ }^{122}$ are the only corrective to the counterproductive imposition of the paradigmatic strictures of late Neo-Assyrian expansion upon these fragmentary and byzantine historical scenarios.

These findings are also a vital qualification to the study of Assyrian imperial 'discourse', essentially the most recent iteration of the 'propaganda' school in Assyrian historiography, demonstrating the potential degree of misunderstanding between the Assyrian heartland and its own peripheries; if Hadi-/Ihtadi-libbušu ever consumed the stuff of Assyrian annals, a doubtful prospect, then it was probably in Aramaic. Indeed, while it must be presumed that this governor of the province of Na'iri visited Ašsur to hobnob with the king and his other magnates at New Year's, dragomen presumably in tow, it can only be speculated as to the contents of his limmu stele, should it ever be found; were an inscription of his to be unearthed at the citadel of Diyarbakır, however, then the present author would wager it reading $h d b l b b h$ mlk' $m d$.

\section{BIBLIOGRAPHY}

Ambos C. 2000, Hadi-libbušu. in H.D. Baker (ed.), The Prosopography of the Neo-Assyrian Empire: Vol. 2, Part I: $H-K$. Using the electronic data base of the Neo-Assyrian Text Corpus Project and the collaboration of numerous colleagues, Prosopography of the Neo-Assyrian Empire 2/1, Helsinki, Neo-Assyrian Text Corpus Project: 438-439.

Andrae W. 1913, Die Stelenreihen in Assur, Wissenschaftliche Veröffentlichungen der Deutschen Orient-Gesellschaft, Leipzig, J. C. Hinrichs'sche Buchhandlung.

Beaulieu P.-A. 2006, Official and Vernacular Languages: The Shifting Sands of Imperial and Cultural Identities in First Millennium B.C. Mesopotamia, in S.L. Sanders (ed.), Margin of Writing, Origins of Culture, (Oriental Institute Seminars 2), Chicago, University of Chicago Press: 191-220.

Brown B. 2013, The Structure and Decline of the Middle Assyrian State: The Role of autonomous and nonstate Actors, Journal of Cuneiform Studies 65: 97-126.

Cole S. W. 1997, The Destruction of Orchards in Assyrian Warfare, in S. Parpola, R. M. Whiting (eds), Assyria 1995: Proceedings of the 10th Anniversary Symposium of the Neo-Assyrian Text Corpus Project Helsinki, September 7-11, 1995, Helsinki, Neo-Assyrian Text Corpus Project: 29-40.

Comfort A., Marciak M. 2018, How Did the Persian King of Kings Get his Wine? The upper Tigris in Antiquity (c.700 BCE to 636 CE), Summertown, Archaeopress.

Dankwarth G., Müller C. 1988, Zur altaramäischen «Altar»-lnschrift vom Tell Ḥalaf, Archiv für Orientforschung 35: $73-78$.

Demsky A. 2008, B’ym (Isa 11:15) = (Bīt-) Bahiān: Resolving an Ancient Crux, Dead Sea Discoveries 15(2): $248-$ 252.

Dewar B. N. 2020, Us against them. Ideological and psychological Aspects of Ashurnasirpal II's Campaign against Assyrian Rebels in Halziluha, Iraq 82: 111-124

Dietrich M. 2003, The Babylonian Correspondence of Sargon and Sennacherib, (State Archives of Assyria 17), Helsinki, Neo-Assyrian Text Corpus Project.

Dornauer A. 2010, Die Geschichte von Gūzāna im Lichte der schriftlichen Zeugnisse, in N. Cholidis, L. Martin

${ }^{122}$ Düring 2020 is very much an archaeological step in the right direction. 
Assyria and Bīt-Zamāni, Hadi-/Iḩtadi-libbušu, and Aramaic in the early Neo-Assyrian State

(eds), Tell Halaf: Im Krieg zerstörte Denkmäler und ibre Restaurierung, (Tell Halaf 5), De Gruyter: 47-67.

Düring B. S. 2020, The Imperialisation of Assyria: An Archaeological Approach, Cambridge, Cambridge University Press.

Dušek J., Mynářová J. 2016, Tell Fekheriye Inscription: A Process of Authority on the Edge of the Assyrian Empire, in J. Dušek, J. Roskovec (eds), The Process of Authority, Deuterocanonical and Cognate Literature Studies 27: 9-39.

Edmonds A. J. 2018, „Warum eroberst du ohne Ende?“: Studies in the Birth of the Neo-Assyrian Empire. Unpublished doctoral thesis, University of Tübingen. Tübingen.

Edmonds A. J. 2019a, A People without Borders? Tracing the shifting Identities and Territorialities of the Ahlameans, in J. Dušek, J. Mynářová (eds), Aramaean Borders: Defining Aramaean Territories in the 10th - 8th Centuries BCE, (Culture and History of the ancient Near East 101), Leiden - Boston, Brill: 26-62.

Edmonds A. J. 2019b, On the Trail of Na'id-Šì HU, Kaskal 16: 323-348.

Elsen-Novák G., Novák M. 2020, Der „kulturelle Code“ des „aramäischen“ Gōzāna (Tall Ḥalaf), in N. Chlodis, E. Katzy, S. Kulemann-Ossen (eds), Zwischen Ausgrabung und Ausstellung: Beiträge zur Archäologie Vorderasiens. Festschrift für Lutz Martin, (marru 9), Münster, Zaphon: 139-172.

Fales F.M. 2010, New Light on Assyro-Aramaic Interference: The Assur Ostracon. in F.M. Fales, G.F. Grassi (eds), CAMSEMUD 2007: Proceedings of the 13th Italian Meeting of Afro-Asiatic Languages. Held in Udine, May 21st - 24th, 2007, (History of Ancient Near East. Monographs 10), Padova, Sargon srl: 189-204.

Fales F.M. 2012, "Hुanigalbat" in early Neo-Assyrian Royal Inscriptions: A retrospective View, in G. Galil, A. Gilboa, A.M. Maeir, D. Kahn (eds), The Ancient Near East in the 12th-10th Centuries BCE. Culture and History: Proceedings of the International Conference held at the University of Haifa, 2-5 May, 2010, (Alter Orient und Altes Testament 392), Münster, Ugarit-Verlag: 99-119.

Fales F.M., Radner K., Pappi C., et al. 2005, The Assyrian and Aramaic Texts from Tell Shiukh Fawqani, in L. Bachelot, F.M. Fales (eds), Tell Shiukh Fawqani. 1994-1998: II, Padova, Sargon srl.: 595-694.

Filippi W. de 1977, The Royal Inscriptions of Aššr-Nasir-Apli II (883-859 B.C.), Assur 1(7): 123-169.

Finkel I.L., Reade J.E. 1998, Assyrian eponyms, 873-649 BC, Orientalia 67(2): 248-254.

Finkelstein J.J. 1953, Cuneiform Texts from Tell Billa, Journal of Cuneiform Studies 7: 111-176.

Folmer M. 2011, Old and Imperial Aramaic, in H. Gzella (ed.) Languages from the World of the Bible: Berlin - Boston, De Gruyter: 128-159.

Forrer E. 1920, Die Provinzeinteilung des assyrischen Reiches, Leipzig, J.C. Hinrichs'sche Buchhandlung.

Frahm E. 2009, Historische und historisch-literarische Texte, Ausgrabungen der Deutschen Orient-Gesellschaft in Assur. E, Inschriften, IX, (Keilschrifttexte aus Assur literarischen Inhalts 3), Wiesbaden: Harrassowitz Verlag.

Fuchs A. 2008, Der Turtān Šamšīilu und die große Zeit der assyrischen Großen. Die Welt des Orients 38: 61-145.

Grayson A.K. 1991, Assyrian Rulers of the Early First Millennium BC: I (1114-859 BC), (The Royal Inscriptions of Mesopotamia. Assyrian Periods 2), Toronto, Buffalo - London, University of Toronto Press.

Grayson A.K. 1994, Studies in Neo-Assyrian History II: The Eighth Century BC, in E. Robbins, S. Sandahl (eds), Corolla Torontonensis: Studies in honour of Ronald Morton Smith, Toronto, TSAR: 73-84.

Grayson A.K. 1996, Assyrian Rulers of the Early First Millennium BC: II (858-745 BC), (The Royal Inscriptions of Mesopotamia. Assyrian Periods, 3), Toronto, Buffalo - London, University of Toronto Press.

Gzella H. 2015, A cultural history of Aramaic: From the beginnings to the advent of Islam, (Handbook of Oriental Studies, Section 1. The Near and Middle East 111), Leiden - Boston, Brill.

Greenblatt J. 2011, The Jewish Neo-Aramaic Dialect of Amadya, (Studies in Semitic Languages and Linguistics 61), Leiden, Brill.

Hoftijzer J., Jongeling K. 1995, Dictionary of the north-west Semitic inscriptions, (Handbook of Oriental Studies, Section 1. The Near and Middle East 21), Leiden, Brill.

Ikeda Y. 1979, Royal Cities and Fortified Cities, Iraq 41(1): 75-87.

Jakob S. 2003, Mittelassyrische Verwaltung und Sozialstruktur: Untersuchungen, (Cuneiform Monographs 29), Leiden - Boston, Brill. 
Kessler K. 1980, Untersuchungen zur historischen Topographie Nordmesopotamiens: Nach keilschriftlichen Quellen des 1. Jahrtausends v. Chr., (Tübinger Atlas des Vorderen Orients. Beiheft 26), Wiesbaden, Dr. Ludwig Reichert Verlag.

Köroğlu K. 2016, Archaeological evidence for the provincial system of the Neo-Assyrian empire in Anatolia, in J. MacGinnis, D. Wicke, T. Greenfield, A. Stone (eds), The provincial archaeology of the Assyrian Empire, McDonald Institute monographs, Cambridge, McDonald Institute for Archaeological Research: 309-320.

Layard A.H. 1853, Discoveries in the Ruins of Nineveh and Babylon: Being the Result of a Second Expedition undertaken for the Trustees of the British Museum, London, John Murray.

Lipiński E. 2000, The Aramaeans: Their ancient history, culture, religion, Orientalia Lovaniensia Analecta 100, Leuven-Sterling, Va., Peeters.

Liverani M. 1992, Studies on the Annals of Ašsurnasirpal II: 2: Topographical Analysis, (Quaderni di Geografia Storica 4), Rome, Università di Roma.

Livingstone A. 1989, Court Poetry and Literary Miscellanea, (State Archives of Assyria 3), Helsinki, Neo-Assyrian Text Corpus Project.

Llop J. 2012, The Development of the Middle Assyrian Provinces, Altorientalische Forschungen 39(1): 87-111.

Machinist P. 1982, Provincial Governance in Middle Assyrian and some new Texts from Yale, Assur 3(2).

Matney T. 2010, Assyrians, Aramaeans, and the Indigenous Peoples of Iron Age Southeastern Anatolia. in S.R. Steadman, J.C. Ross (eds), Agency and identity in the ancient Near East: New Paths Forward, Approaches to Anthropological Archaeology, London, Equinox: 129-147.

Matney T., MacGinnis J., Wicke D., Köroğlu K. 2020, Eighteen years on the frontiers of Assyria: the Ziyaret Tepe Archaeological Project, in K. Gavagnin, R. Palermo (eds), Imperial frontiers. Interactions and Expansion from Assyria to the Roman Period: Proceedings of the 5th "Broadening Horizons" Conference (Udine 5-8 June 2017). Volume 2, Trieste, Edizioni Università di Trieste: 85-118.

Mattila R. 2000, The King's Magnates: A Study of the Highest Officials of the Neo-Assyrian Empire, State Archives of Assyria Studies 11, Helsinki, Neo-Assyrian Text Corpus Project.

Millard A.R. 1994, The Eponyms of the Assyrian Empire 910-612 BC, State Archives of Assyria Studies 2, Helsinki, Neo-Assyrian Text Corpus Project.

Millard A.R. 2008, Aramaic at Nimrud on Clay, Potsherds, Bricks and Ivories, in J. E. Curtis, H. McCall, D. Collon, L. al-Gailani Werr (eds), New Light on Nimrud: Proceedings of the Nimrud Conference 11th-13th March 2002, London, British Institute for the Study of Iraq: 267-270.

Olmstead A.T. 1918, The calculated Frightfulness of Ashur Nasir Apal, Journal of the American Oriental Society 38: 209-263.

Parker B.J. 2001, The Mechanics of Empire: The Northern Frontier of Assyria as a Case Study in Imperial Politics, Helsinki, Neo-Assyrian Text Corpus Project.

Parpola S. 2017, The Location of Rașappa. in Y. Heffron, A. Stone, M. Worthington (eds), At the Dawn of History: Ancient Near Eastern Studies in Honour of J.N. Postgate, Volume 2, Winona Lake In., Eisenbrauns: 393-412.

Pomeroy S.B. 1986, Copronyms and the Exposure of Infants in Egypt, in R.S. Bagnall, W. V. Harris, (eds), Studies in Roman law in memory of A. Arthur Schiller, Leiden, Brill: 147-162.

Pongratz-Leisten B. 2011, Assyrian royal discourse between local and imperial traditions at the Habur, Revue d'assyriologie et d'archéologie orientale 105(1): 109-128.

Postgate J.N. 1992, The Land of Assur and the Yoke of Assur, World Archaeology 23(3, Archaeology of Empires): 247-263.

Postgate J.N. 1995, Assyria: The Home Provinces, in M. Liverani (ed.) Neo-Assyrian Geography, (Quaderni di Geografia Storica 5), Padova, Sargon srl: 1-17.

Radner K. 2004, Das mittelassyrische Tontafelarchiv von Giricano/Dunnu-ša-Uzibi, (Ausgrabungen in Giricano 1), Turnhout, Brepols.

Radner K. 2006a, How to reach the Upper Tigris: The route through the Tür 'Abdinn, State Archives of Assyria Bulletin 15: 273-305. 
Radner K. 2006b, Provinz. C. Assyrien, Reallexikon der Assyriologie 11(1/2): 42-68.

Radner K., Schachner A. 2001, Tušhan'dan Amēdi'ye / From Tušhan to Amēdi, in N. Tuna, J. Öztürk, J. Velibeyoglu (eds), Salvage Project of the Archaeological Heritage of the Ilsu and Carchemish Dam Reservoirs: Activities in 1999, Ankara, METU: 729-776.

Reade J.E. 2012, Visual Evidence for the Status and Activities of Assyrian Scribes, in G.B. Lanfranchi, D. Morandi Bonacossi, C. Pappi, S. Ponchia (eds), Leggo! Studies presented to Frederick Mario Fales on the occasion of his 65th birthday, (Leipziger altorientalistische Studien 2), Wiesbaden, Harrassowitz Verlag: 699-718.

Roaf M., Schachner A. 2005, The Bronze Age to Iron Age Transition in the Upper Tigris Region. New Information from Ziyaret Tepe and Giricano, in A. Çilingiroğlu, G. Darbyshire (eds), Anatolian Iron Ages V: Proceedings of the Fifth Anatolian Iron Ages Colloquium Held at Van, 6-10 August 2001, London, British Institute of Archaelogy in Ankara: 115-123.

Rolfe J.C. 1950, Ammianus Marcellinus. History, Volume I: Books 14-19, Cambridge, Ma., Harvard University Press.

Röllig W. 1983, Ein ltinerar aus Dur-Katlirnmu, Damaszener Mitteilungen 1: 279-284.

Sano K. 2015, Ist Ilānu der Bruder des Bur-Ramānu?, Nouvelles Assyriologiques Brèves et Utilitaires 2015(2): 62, no. 42.

Schachner A. 2018, Orta Assur Krallarının Anadolu'daki Çıkarları/The Anatolian Interests of the Middle Assyrian Kings, in K. Köroğlu and S. F. Adalı (eds), Assurlular: Dicle'den toroslar'a Tanrı Assur'un Kralliğı / The Assyrians - kingdom of the god Ašsur from Tigris to Taurus, (Anadolu uygarlıkları serisi, 7), Istanbul, Yapi Kredi Yayinlar1.

Szuchman J. 2009, Bit Zamani and Assyria, Syria 86: 55-65.

Wicke D. 2013, Itti niše kurAššur amnūšunūti. „Zu den Leuten Assyriens zählte ich sie“. Beobachtungen zum kulturellen Austausch am Oberen Tigris in neuassyrischer Zeit, in T. R. Kämmerer, S. Rogge (eds), Patterns of Urban Societies, Münster, Ugarit-Verlag: 233-254.

Wilson J.V.K. 1972, The Nimrud Wine Lists: A study of men and administration at the Assyrian capital in the eighth century B.C., (Cuneiform texts from Nimrud 1), London, British School of Archaeology in Iraq.

Younger K.L. Jr. 2016, A Political History of the Arameans, Atlanta, Society of Biblical Literature Press.

Zadok R. 1991, Elements of Aramean Pre-History, in M. Cogan, I. Eph 'al (eds), Ah, Assyria... Studies in Assyrian history and ancient Near Eastern historiography presented to Hayim Tadmor, (Scripta Hierosolymitana, 33), Jerusalem, The Magnes Press: 104-117. 